\title{
A CONSTRUÇÃO dA FACE COMO ESTRATÉGIA ARGUMENTATIVA NO FILME "EL PATRÓN: A RADIOGRAFIA DE UN CRIMEN"
}

\author{
Araceli Covre Silva ${ }^{1}$
}

\begin{abstract}
Resumo: No discurso jurídico, o trabalho argumentativo é condição sine qua non para que os interlocutores em potencial (autor e réu) alcancem os objetivos por eles propostos. Assim, cada participante de uma interação expressa uma avaliação de si e do outro cuja construção se estabelece no evento comunicativo no qual está inserido, o que conduz à Teoria de Elaboração de Face (GOFFMAN, 1980, 2011). Associada à ideia de preservação da face, Brown e Levinson (1987 [1978]) apresentam a teoria da Polidez, na qual há atos que ameaçam as faces dos interlocutores. Em textos jurídicos, cujo processo comunicativo envolve a luta por um suposto direito, é imprescindível que os interlocutores saibam construir sua argumentação. Com base nessa premissa, a proposta deste artigo é mostrar como os princípios pragmáticos dos Atos de Fala (AUSTIN, 1990 [1962]), da Face, (GOFFMAN, 1980, 2011) e da Polidez (BROWN e LEVINSON, 1987 [1978]) são essenciais para a construção de um discurso argumentativo.
\end{abstract}

Palavras-chave: Pragmática. Atos de Fala. Face. Polidez. Argumentação.

Abstract: Regarding legal discourse, the argumentative work is the sine qua non condition in order to make the potential interlocutors (author and defendant) achieve the goals they have proposed. Thus, each participant of an interaction expresses a self and the other evaluation whose construction is stablished in the communicative event in which it is inserted, what leads to the Face Elaboration Theory (GOFFMAN, 1980, 2011). Associated to the face preservation's idea, Brown and Levinson (1987 [1978]) present the theory of Politeness, in which shows acts that threaten the interlocutors faces. In legal texts, which the communicative process concerns the fight for an alleged right, it is indispensable that the interlocutors are capable to build an argumentation. Based on this premise, this article aims at showing how the pragmatic principles of Acts of Speech, (AUSTIN, 1990 [1962]), Face, (GOFFMAN, 1980, 2011) and Politeness, (BROWN and LEVINSON, 1987 [1978]) are essential for the construction of an argumentative speech.

Keywords: Pragmatic. Acts of Speech. Face. Politeness. Argumentation.

\section{Considerações Iniciais}

\footnotetext{
${ }^{1}$ Doutora em Linguística. Programa de Pós-graduação em Linguística (PPGEL), UFES, Vitória, Espírito Santo, Brasil. E-mail: aracelicovre@ hotmail.com.
} 
A vida com justiça é que é o objeto do direito. E a vida é justa quando garantida a dignidade da experiência humana. Vida com fome não é justa nem digna. Vida com dor também não, seja qualquer a espécie de dor que acometa o homem. A vida tocada pelo medo e pela angústia é experiência malsã, mais ainda se o desequilíbrio vem de fora. (Carmen Lúcia A. Rocha)

Iniciamos nosso diálogo versando sobre a vida e o direito porque este é requisitado quando se tem um desequilíbrio nas relações sociais, quando há um embate no qual se tira de outrem o direito de viver com dignidade. Reestabelecer o convívio humano passa pelo trabalho com a linguagem, pois por meio dela manifestamos anseios, angústias, revelamos quem somos, o que nos tira ou devolve a paz. Direito e linguagem se entrecruzam, esta é condição para manifestação daquele.

Propomos neste texto, à luz da perspectiva pragmática, sob o prisma da Teoria dos Atos de Fala (AUSTIN, 1990 [1962]), da Elaboração da Face (GOFFMAN, 1980, 2011) e da Polidez (BROWN e LEVINSON, 1987 [1978]) lançar um olhar sobre o processo interativo da área jurídica tendo como pano de fundo a análise do filme $E l$ patrón: a radiografia de un crimen, autoria de Elias Neuman, dirigido por Sebastián Schindel, produzido em 2014, na Argentina. Nele é possível observar como as teorias elencadas são essenciais para a produção argumentativa e a defesa de um direito.

Traçamos um percurso teórico cujas bases emergem da definição de Pragmática, passando pelas concepções de atos de fala, face e polidez, para, então, delinearmos a interação presente na esfera jurídica, seus atores, propósitos e mecanismos de construção argumentativa.

\section{Os vieses da Pragmática}

A Pragmática é uma vertente de estudos linguísticos cujo tópico central de trabalho é a linguagem em uso. Sabemos que há outras vertentes no qual o uso também é a mola propulsora de análises, como a sociolinguística, o funcionalismo entre outras. No entanto, há que se destacar o principal fundamento do viés pragmático: a intenção do falante evidenciado nos usos linguísticos. Armengaud (2006, p. 9) revela o que exatamente se quer quando um estudioso lança um olhar pragmático sobre um objeto: 
(...) uma tentativa de responder a perguntas como: que fazemos quando falamos? Que dizemos exatamente quando falamos? Por que perguntamos o nosso vizinho de mesa se ele pode nos passar o sal, quando é flagrante e manifesto que ele pode? Quem fala e com quem? Quem você acha que sou para me falar desse modo? [...] O que é uma promessa? Como alguém pode dizer uma coisa completamente diferente daquilo que queria dizer? Podemos confiar no sentido literal de uma frase? Quais são os usos da linguagem? (ARMENGAUD, 2006, p. 9, itálico no original).

Entender como se dá o processo comunicativo, como a interação acontece, quais são as reais intenções daquele que faz uso da palavra é o que rege o olhar pragmático. Se tomarmos o significado da palavra comunicação, do latim communicare, cujo sentido é tornar comum uma ideia, já nasce uma primeira indagação: como fazer para que a nossa ideia chegue da forma como desejamos ao outro? Como fazer com que ele compreenda a nossa intenção? Para alcançar êxito em tal empreitada, há muitas variáveis envolvidas: quem fala com quem? Há proximidade entre os interlocutores ou não? Qual o contexto dessa fala? Trata-se de uma interação pública ou privada? Essas são questões basilares para a construção de falas mais produtivas, que tenham mais probabilidade de alcançar o outro da forma como o locutor almeja.

Acreditamos que dois pilares essencialmente pragmáticos contribuem para a produção de discursos mais eficazes no processo comunicativo: a Teoria dos Atos de Fala e a Elaboração da Face, associados às estratégias de polidez. Como a intenção neste artigo é mostrar os princípios pragmáticos fundadores dessas teorias funcionando na esfera jurídica, apresentamos as teses centrais de cada uma delas.

\section{Teoria dos Atos de fala}

Austin (1990[1962], precursor da Teoria dos Atos de Fala, inaugura, com a publicação da obra How to do things with words, a ideia de que todo dizer revela um fazer. Embora essa afirmação não fosse exatamente uma novidade, pois já estava presente nos estudos da ciência retórica, conforme Kerbrat Orecchioni (2005), foi com seu precursor que ela ganhou força. Os estudos de Austin evidenciavam que quando 
produzimos um ato, não apenas expressamos algo, mas realizamos algo. Essa percepção define a performatividade.

Se ao dizer algo a realizamos, a tese central de Austin (1990[1962] é o fato de que a linguagem é ação. Assim, o proferimento de qualquer sentença incide sobre alguém porque em qualquer situação de comunicação há um fazer, há uma relação entre os interlocutores que assumem funções sociais no momento da interação. As funções assumidas pelos interlocutores, bem como o local onde a comunicação se dá, definem o que pode ou não ser dito para que um ato de fala tenha validade. Logo, a preocupação austiniana não é saber a veracidade ou a falsidade de um ato, como buscavam os adeptos à lógica, mas reconhecer as condições de produção de atos que os tornem válidos no sentido de produzirem efeitos. No âmbito jurídico, por exemplo, juiz e advogados (representantes das partes processuais) são os interlocutores centrais. No espaço do tribunal, o juiz, ao proferir a sentença "eu te condeno a 10 anos de prisão" cria uma nova condição para o interlocutor: de homem livre para alguém condenado. Para que esse ato tenha validade, é imprescindível que todos os participantes dessa interação estejam investidos de papéis sociais específicos e estejam em espaços institucionais que os autorizem a exercer esses papéis.

Pelo exposto, temos que toda interação ocorre num contexto específico e esse contexto revela quem somos e como podemos nos dirigir a outrem para obtermos êxito. Para interagirmos, utilizamos atos de fala, daí conhecer suas formas e funções tornase importante. Metodologicamente, Austin (1990[1962] dividiu os atos de fala em três tipos:

Quadro 1 - Tipos de atos de fala

\begin{tabular}{|l|l|l|}
\hline & Tipo de ato de fala & Caracterização do ato \\
\hline 1 & Locucionário & Expressão linguística, conteúdo expresso \\
\hline 2 & Ilocucionário & Função do ato (afirmar, perguntar, prometer etc.) \\
\hline 3 & Perlocucionário & Efeito do ato \\
\hline
\end{tabular}

Fonte: A autora (2020).

É claro que esses três atos atuam conjuntamente, pois toda ação comunicativa é constituída por atos linguisticamente organizados que carregam uma intenção, e o 
falante espera que essa intenção seja reconhecida pelo ouvinte. Como pontua Mari (2001, p. 95), “(...) ainda que os atos sejam construídos a partir de uma intervenção direta do locutor, que mantém compromissos com sua consecução, eles são essencialmente orientados para o outro, sendo, portanto, um objeto que requer um processo interativo por necessidade".

Com o intuito de categorizar as formas que os atos de fala podem se revestir, de acordo com a sua força ilocucionária, Austin (1990[1962] propõe cinco classes de proferimentos: veriditivo, exercitivo, comissivo, comportamental e expositivo. Essa proposta será ampliada por Searle (1981), mas antes de apresentá-la, vale salientar que Austin (1990[1962], ao defender a tese de que dizer é fazer, estabelece que haja atos cuja emissão já revela um fazer, há uma ação simultânea, como sinalizamos no exemplo eu te condeno a 10 anos de prisão. Nesse caso, trata-se de um performativo explícito. No entanto, quando se diz o réu é culpado, embora não haja um performativo expresso, o proferimento foi feito e, se atendidas suas condições de sucesso (pessoas autorizadas, ritos convencionais para efetividade do ato), a performatividade ocorreu.

Há atos cuja natureza não realiza uma ação simultânea, apenas descrevem um estado de coisas, são os chamados constatativos. Contudo, não importa se um ato é performativo ou constatativo, o essencial é reconhecer que tanto um quanto o outro apresenta um propósito subjacente. A finalidade comunicativa se manifesta por meio das escolhas feitas pelo falante, com base no que ele acredita ser mais eficaz para alcançar o seu intento. Se um falante deseja que o ouvinte faça algo para ele, numa relação entre chefe e subordinado, por exemplo, ele pode valer-se da classe que Austin (1990[1962] denominou exercitivos, pois nessa classe estão inseridas as relações de ordem.

Num primeiro momento, poderíamos até pensar que essa classificação proposta por Austin (1990[1962] seja reducionista, considerando que as relações interacionais são complexas e, certamente, não seria possível circunscrevê-las em apenas cinco classes. Entretanto, acreditamos que o autor propõe essa classificação como uma forma de pensar a força impressa num ato de fala, pois, sendo performativo ou não, em todo ato de fala há uma intenção. Todos os atos de fala guardam uma força ilocucionária porque em todos a intencionalidade do falante se faz presente. Conforme pontuamos, Searle (1981), na esteira de Austin (1990 [1962]), sistematiza as condições de produção dos atos cujo intuito é pensar na força ilocucionária presente neles. 
PERcursos Linguísticos • Vitória (ES) • v. 10 • n. 26 • 2020 • ISSN: 2236-2592 •

Dossiê: Linguagem, Comunicação e Cognição•

Quadro 2- Tipos de atos e características

\begin{tabular}{|l|l|l|}
\hline & Tipo de ato & Características \\
\hline 1 & Assertivo & $\begin{array}{l}\text { Retratam algo presente no mundo; predicam algo. Por esse } \\
\text { motivo são estruturados em forma de afirmativas, testemunhos } \\
\text { entre outros. }\end{array}$ \\
\hline 2 & Diretivo & $\begin{array}{l}\text { Determinam algo; formas utilizadas pelo locutor para exigir } \\
\text { que o interlocutor faça algo. São expressos por meio de } \\
\text { sentenças imperativas e perguntas. }\end{array}$ \\
\hline 3 & Comissivo & $\begin{array}{l}\text { Revelam a disposição do locutor para realizar algo para o } \\
\text { interlocutor. As promessas exemplificam esse ato tipo de ato. }\end{array}$ \\
\hline 4 & Expressivo & $\begin{array}{l}\text { São atos convencionais para expressar agradecimentos, } \\
\text { cumprimentos entre outros. }\end{array}$ \\
\hline 5 & Declarativo & $\begin{array}{l}\text { São os performativos por natureza; criam ou modificam uma } \\
\text { situação. }\end{array}$ \\
\hline
\end{tabular}

Fonte: A autora (2020).

Searle (1981, p. 43) salienta que nem todos os atos têm um conteúdo proposicional, como um “ai!", por exemplo. Considerando que os atos são expressos sempre com uma intenção e o reconhecimento da força ilocucionária pelos interlocutores é fundamental, é mister pontuar que "os processos utilizados em português para marcar esta força ilocucional incluem, pelo menos, a ordem das palavras, o acento tônico, a entoação, a pontuação, o modo do verbo e os verbos chamados performativos" (SEARLE, 1981, p. 43). Resta claro, então, que não só as escolhas léxico-verbais são importantes para a produção discursiva do falante, mas também a ordem das estruturas linguísticas e suas marcas entoacionais. Temos convicção de que uma comunicação mais produtiva, no sentido de ter mais probabilidade de atingir o interlocutor da forma desejada, exige que o locutor pense em quem ele é e quem é o outro no momento da interação, no contexto específico. O tipo de ato a ser escolhido depende da intenção de quem o profere e, também, das condições para proferi-lo.

A teoria dos atos de fala nos permite concluir que todo ato é controlado por regras, a produção de um ato está sempre inserida num contexto específico e esse 
contexto rege o que é permitido ou não em termos de produção discursiva. Contudo, às vezes o falante tem a intenção de transgredir a norma, de burlar as convenções para um determinado fim. Esse rompimento com as normas preestabelecidas provoca reações, geram efeitos que podem ser positivos ou não. A escolha dos atos promove a construção de face positiva ou negativa dos interlocutores, como discorremos no próximo item.

\section{Teoria da Elaboração da Face}

A Teoria de Elaboração da Face foi proposta pelo sociólogo Erwin Goffman cuja ideia fulcral é: "todo homem, sempre e em todo lugar, mais ou menos conscientemente, representa um papel" (2011, p. 27). Essa afirmativa revela que o homem é diverso, múltiplo: dependendo do ambiente no qual se encontra ele se reveste do personagem que melhor lhe convém. Essa ideia de Goffman é comumente metaforizada pela figura do teatro. Somos atores sociais, não somos os mesmos o tempo todo, ora exercemos papel de mãe, ora de amiga, ora de profissional, cada um deles requer uma atuação diferente.

As sociedades, de uma forma geral, estão organizadas dentro de padrões ritualizados. De acordo com Goffman (2011), elas

precisam mobilizar seus membros como participantes autorreguladores em encontros sociais. Uma forma de mobilizar o indivíduo para esse propósito é através do ritual; ele é ensinado a ser perceptivo, a ter sentimentos ligados ao eu e um eu expresso pela fachada, a ter orgulho, honra, dignidade, a ter consideração, tato e uma certa quantidade de aprumo. [...] A capacidade de ser limitado por regras morais pode muito bem pertencer ao indivíduo, mas o conjunto particular de regras que o transforma num ser humano é derivado de requerimentos estabelecidos na organização ritual de encontros sociais (GOFFMAN, 2011, p. 51).

Pelo exposto, por mais que cada ser tenha a sua individualidade, na convivência social há regras que precisam ser observadas. Cada pessoa tem o direito moral de esperar que seu interlocutor o trate com respeito. Vale lembrar que essas regras fazem parte de uma determinada cultura, por isso é importante mencionar que o que é considerado respeitoso em uma cultura pode não ser em outra. O que podemos 
considerar como universal é o fato de os indivíduos desejarem ser bem quistos pelo outro, por isso eles reivindicam para si uma face definida como "o valor social positivo que uma pessoa efetivamente reivindica para si mesma através da linha de ação que os outros pressupõem que ela assumiu durante um contato particular. A fachada é uma imagem do eu delineada em termos de atributos sociais aprovados" (GOFFMAN, 2011, p. 15-16)

Os estudos goffmanianos conduzem à percepção de que, quando interagimos, assumimos uma linha de ação que nos permita expressar pontos de vista, considerando a situação, o outro e a nós mesmos. Nessa trilha, Brown e Levinson (1987) revisitam o conceito de face e assim a definem:

face é a imagem que todo membro quer reivindicar para si mesmo e consiste em dois aspectos relacionados (a) face negativa: reivindicação básica de território, reservas pessoais, liberdade de ação, liberdade de imposição; (b) autoimagem positiva (incluindo o desejo de que esta autoimagem seja apreciada e aprovada [...] Assim, a face é algo que é investido emocionalmente e que pode ser perdido, mantido ou aprimorado ${ }^{2}$ (BROWN; LEVINSON, 1987, p. 61).

Brown e Levinson (1987 [1978]) partem do pressuposto de que os interlocutores têm uma face positiva e uma negativa; há um interesse mútuo de manutenção de suas faces. No entanto, nada impede que essa face possa ser quebrada, pois, para chegar ao seu objetivo comunicacional, pode ser que atacar o ouvinte seja uma estratégia do falante. A interação no ambiente jurídico certamente é um dos principais eventos comunicativos no qual romper com a cooperatividade, com harmonia das relações, com a preservação de faces seja até uma condição para conseguir o que se deseja. Nesse ambiente, as relações entre os atores sociais já estão estremecidas, quando um processo é autuado na via judicial presume-se que o acordo entre as partes não foi possível, tornando-se o acesso à Justiça necessário.

\footnotetext{
${ }^{2}$ No original lê-se: Face the public self-image that every member wants to claim for himself, consisting in two related aspects: (a) negative face: the basic claim to territories, personal preserves, rights to no distraction - i. e. freedom of action and freedom from imposition (b) positive face: the positive consistent self-image or 'personality' (crucially including the desire that this self-image be appreciated and approved of) claimed by interactants. [...] Thus face is something that is emotionally invested and that can be lost, maintained, or enhanced.
} 
Tendo em vista que o falante assume uma linha de ação e esta nem sempre é orquestrada harmonicamente, Brown e Levinson (1987 [1978]) asseguram que há formas de ameaçar a face dos interlocutores. São elas:

Quadro 3 - Atos de ameaça à face

\begin{tabular}{|l|l|ll|}
\hline & Atos de ameaça à face & Característica & \\
\hline 1 & $\begin{array}{l}\text { Atos de ameaça à face positiva do } \\
\text { locutor }\end{array}$ & $\begin{array}{l}\text { atos que destacam a fraqueza e } \\
\text { limitação da pessoa }\end{array}$ \\
\hline 2 & $\begin{array}{l}\text { Atos de ameaça à face negativa do } \\
\text { locutor }\end{array}$ & $\begin{array}{l}\text { atos que constrangem a liberdade de } \\
\text { ação }\end{array}$ \\
\hline 3 & $\begin{array}{l}\text { Atos de ameaça à face positiva do } \\
\text { ouvinte }\end{array}$ & $\begin{array}{l}\text { atos que critiquem ou reprovem o } \\
\text { interlocutor }\end{array}$ \\
\hline 4 & $\begin{array}{l}\text { Atos de ameaça à face negativa do } \\
\text { ouvinte }\end{array}$ & $\begin{array}{l}\text { atos que exijam uma ação do } \\
\text { interlocutor }\end{array}$ \\
\hline
\end{tabular}

Fonte: A autora (2020).

Ao participar de uma interação, é possível que os atos produzidos pelos interlocutores se constituam em atos de ameaça à face tanto do falante quanto do ouvinte: admitir um erro, por exemplo, desvaloriza a face positiva do locutor na medida em que ele revela a outrem sua fraqueza; fazer uma pergunta de caráter mais íntimo a uma pessoa com quem não se tem muita intimidade (nos termos de Goffman, invasão de "território") ameaça à face negativa do interlocutor, porque exige dele uma resposta, ao mesmo tempo em que pode ser também uma ameaça à face positiva do locutor, pois ele pode ser visto como uma pessoa indiscreta.

Brown e Levinson (1987 [1978]) assinalam ainda que os atos de ameaça à face podem ser explícitos ou não; podem conter uma expressão corretiva ou não; se houver uma expressão corretiva, ela pode revelar uma face positiva ou negativa, dependendo dos efeitos desejados e também da relação entre os participantes. Imaginemos uma situação na qual Maria queira pedir o vestido de sua amiga Joana emprestado. Um pedido como esse, por exemplo, é um ato de ameaça à face negativa do ouvinte, mas o locutor pode fazê-lo de forma reparadora ( $\mathrm{O}$ que você acha de me emprestar seu vestido?) ou não (Me empresta seu vestido). Ressalta-se que o grau de ameaça à face está diretamente relacionado ao contexto e aos fatores de ordem psicossocial e interacional. Dentre esses fatores, Brown e Levinson (1987 [1978]) destacam: (a) a 
distância social entre os interlocutores; (b) a diferença de poder entre eles; (c) as imposições culturais.

Com base nas observações de Brown e Levinson (1987 [1978]), podemos concluir que os atos são produzidos para cumprir uma dada finalidade e circular em esferas discursivas específicas. Cada uma dessas esferas tem parceiros legítimos que dela participam e, a depender da relação estabelecida entre eles e de suas intenções, os atos vão ser mais ou menos ameaçadores. $\mathrm{O}$ falante é quem escolhe suavizar ou não um ato; ser polido ou não depende da disposição do falante, pois é ele quem tem a posse da fala.

Se o falante tem a opção de ser polido ou não e polidez se relaciona ao "esforço empreendido para mostrar preocupação com a face do outro" (LINS e MARCHESI, 2010, p. 2381), há estratégias que contribuem para que os interlocutores preservem a face uns dos outros ou não. De acordo com Brown e Levinson (1987 [1978]), constroise uma polidez positiva quando se busca atender os interesses e necessidades do ouvinte, quando se evita a discordância, quando se reforça pontos de vista comuns, quando se busca incluir o ouvinte na atividade, enfim, há uma preocupação com outro, em deixá-lo confortável. Entretanto, quando não se é simpático, quando se desvaloriza as atitudes do outro ou ainda quando são feitas perguntas diretas, sem modalizações, tem-se a polidez negativa.

Tendo como alicerce o aspecto acional da linguagem (AUSTIN, 1990 [1962]), a ideia de que preservação de face é inerente a quaisquer interações (GOFFMAN, 2011), e que a polidez é parte integrante desse ambiente interacional no sentido de estar associada às regras de preservação de face para fins de harmonizar ou não as relações (BROWN e LEVINSON, 1987 [1978]), tecemos algumas considerações sobre os atos de fala presentes no filme proposto para análise.

\section{Uma aplicação pragmática}

Com base na exposição teórica, apresentamos a análise de alguns excertos do filme El patrón: a radiografia de un crimen guiados pelos princípios teóricos elencados. Todavia, para fins de contextualização, é preciso salientar o enredo da narrativa. A história, baseada em fatos reais, aborda a trajetória de Hemógenes, homem 
humilde que vai com sua esposa para a cidade grande em busca de trabalho e de uma vida melhor. Ao chegar à cidade consegue trabalho num açougue cujo patrão, Latuada, o obriga a vender carne em mau estado de conservação. As cenas fílmicas registram as condições sub-humanas e de escravidão a que Hemógenes era submetido por Latuada. Com o passar do tempo, o empregado, por não suportar mais o ambiente opressivo no qual vivia, mata o patrão. Os trechos transcritos para análise fazem parte das cenas do processo de julgamento as quais dividimos em três blocos: (1) momento no qual uma médica entrevista Hemógenes após ele ter tentado o suicídio; (2) discurso do promotor; e (3) discurso do advogado de defesa.

\section{Bloco 1 - Entrevista da médica com Hemógenes}

No decorrer do filme constrói-se uma face positiva de Hemógenes no sentido de criar a imagem de homem trabalhador, humilde, simples e honesto, sem traços de agressividade até o momento em que ele comete o assassinato. $\mathrm{O}$ fato de ter matado um homem o atormentava, motivo pelo qual ele atenta contra a própria vida. No trecho a seguir, é possível perceber a autopunição do réu.

Médica - Hermógenes, por que você se feriu assim? Você fez isso pensando em quê?

Hermógenes - Na minha mulher e na minha filha. E também que matei um homem. Isso não tem perdão. Ele sofreu muito.

Médica - Hermógenes você sente uma grande culpa pelo que fez. Isso é normal. Mas culpa e responsabilidade são coisas diferentes. Fale sobre o seu chefe. Como ele era?

Hermógenes - Ele não era bom. Deus não o fez bom. Sempre estava zangado e malhumorado. Nunca me disse, me cumprimentou. Ele me fez passar vergonha muitas vezes. Ele não era de ajudar os empregados.

Médica - Se seu patrão era tão ruim, por que você não foi embora?

Hermógenes - Para onde? Onde encontrar outro emprego? Não é fácil. Assim pelo menos eu podia dar um dinheirinho a Gladys. E eu sempre pensava que as coisas acabariam melhorando. Ele prometeu o apartamento, prometeu que ia dar aumento, prometia que ia pagar o que me devia.

Médica - Você pensa no que fez? Nas razões disso ter acontecido?

Hermógenes - Sim. Penso. Cada dia mais.

Médica - E o que você pensa?

Hermógenes - Eu sempre fui alguém que dizia que matar alguém é errado. Eu penso e insisto nisso. Matar é errado, mas aconteceu logo comigo. Quando aconteceu foram apenas quinze segundos. Eu penso muito nisso. Muito mesmo. É como se eu estivesse cumprindo a minha sina.

Médica - O seu destino era matá-lo? 
Hermógenes - É claro. É como se ele estivesse me preparando para isso. Ele me fez fazer coisas muito feias. É como se a minha tristeza fosse a alegria dele. Eu era escravo dele. Um escravo de confiança.

Como se trata de um diálogo circunscrito na esfera jurídica, sabemos que o ato de fala assertivo sempre estará presente e de forma preponderante porque cumpre a função de descrever um estado de coisas, seja sob a forma de pergunta, de afirmativa, entre outras. Nesse diálogo específico, as perguntas diretas, sem traços de ironia, por exemplo, são postas no sentido de buscar respostas objetivas em relação à atitude de Hemógenes, como se vê em: Hermógenes, por que você se feriu assim? Você fez isso pensando em quê?, ao que ele responde também de forma direta: Na minha mulher e na minha filha. E também que matei um homem. Isso não tem perdão. Ele sofreu muito. São atos de fala nos quais o produtor expressa seus sentimentos de culpa e ameaçam a sua face positiva sobretudo quando enuncia "matei um homem" e "isso não tem perdão". A autopunição é percebida exatamente pela força ilocucionária revelada por meio dessas declarações. No dicionário, matar, em sua primeira acepção, é "tirar a vida de (alguém) intencionalmente; assassinar, <m. alguém com um tiro > <não matarás, diz um dos mandamentos de Deus> (HOUAISS, 2001, p. 1866). É perceptível que a carga semântica do verbo "matar" associada à negativa "não tem perdão" faz com que o interlocutor possa reconhecer não uma mera afirmação, mas uma declaração de culpa cujo ato é imperdoável.

É oportuno lembrar que, no âmbito jurídico, a interação se estabelece entre dois litigantes (autor e réu) e o juiz. No caso em tela, temos o advogado de defesa do protagonista Hemógenes e o promotor de justiça. Este tem a função de mostrar a culpabilidade do réu e aquele a inculpabilidade. Quando não é possível declarar a inocência do representado, o advogado de defesa precisa reconstruir a história com o intuito de justificar as ações do acusado e quem sabe fazer com que ele deixe de ser visto como autor do crime e passe a ser vítima. Essa transfiguração de criminoso à vítima vai sendo delineada justamente pela seleção dos atos de fala e pela construção da face positiva do protagonista (empregado) e da face negativa do antagonista (patrão). Na sequência do diálogo, Hemógenes, a pedido da médica, assim descreve seu chefe: Ele não era bom. Deus não o fez bom. Sempre estava zangado e malhumorado. Nunca me disse, me cumprimentou. Ele me fez passar vergonha muitas 
vezes. Ele não era de ajudar os empregados. Trata-se de atos de fala que revelam a face negativa de Latuada, atos construídos por meio de palavras que o desqualificam (zangado, mal humorado), atos que negam boa conduta (não era bom, nunca me cumprimentou, não era de ajudar os empregados). As construções negativas são constantes em discursos cujo objetivo é se contrapor a um dito, é refutar uma informação, é destacar atitudes negativas de outrem. O uso do advérbio não é recorrente nos textos da esfera jurídica, justamente por funcionarem como um recurso linguístico de contraposição a um dito.

Se o empregado tinha consciência das atitudes maléficas de seu patrão, vale a pergunta proferida pela médica: Por que você não foi embora? Hemógenes responde com outra pergunta: Para onde? Onde encontrar outro emprego? Não é fácil. [...] Ele prometeu o apartamento, prometeu que ia dar aumento, prometia que ia pagar o que me devia. Sabemos que uma pergunta é um ato ilocucionário que expressa a intenção do locutor. Em outras palavras, há uma convenção aceita de que quando o falante profere uma pergunta espera uma resposta de seu ouvinte. Quando este responde com outra pergunta, muitas vezes o faz por entender que a resposta é óbvia, não foi embora porque não tinha nem lugar para ir, nem emprego. Além disso, na perspectiva do réu, como seu patrão havia prometido dar aumento e pagar o que devia, ele decidiu ficar. Essa decisão advém da promessa de Latuada, afinal trata-se de um ato que coloca o locutor numa posição de quem fará algo em favor do interlocutor. Havia uma expectativa por parte de Hemógenes de que a promessa seria cumprida.

Pela construção do diálogo entre a médica e o acusado, é possível perceber a passagem progressiva da confissão do crime ao arrependimento, pois, o réu, ao ser perguntado sobre o que ele pensa, sobre o seu destino, responde: Eu sempre fui alguém que dizia que matar alguém é errado. Eu penso e insisto nisso. Matar é errado, mas aconteceu logo comigo. Quando aconteceu foram apenas quinze segundos. Eu penso muito nisso. Muito mesmo. É como se eu estivesse cumprindo a minha sina. Há uma sucessão de atos assertivos os quais revelam o estado do falante. De acordo com Mari (2001, p. 113), os atos assertivos ajustam-se numa direção palavra-mundo porque "são palavras que se ajustam a um determinado estado de coisas previamente ocorrido no mundo".

As asserções evidenciam fatos, por isso são fundamentais para as construções discursivas. Além disso, elas podem ser revestidas sob a forma de uma afirmação, de 
um testemunho, de uma suposição, entre outras. No discurso jurídico, asserções são preponderantes dado esse caráter de exposição de ocorrências do mundo, de representação do real, ou pelo menos do que se acredita ser real e existir no mundo. As respostas dadas por Hemógenes são predominantemente assertivas, pois revelam o seu pensar sobre os acontecimentos, sobre suas ações. O discurso do promotor segue essa mesma linha assertiva. Vejamos:

\section{Bloco 2 - Discurso do promotor}

Tendo analisado todos os elementos e ouvido os especialistas e testemunhas fica claro que o motor do crime é o ódio do réu contra o seu empregador. Ele o responsabiliza por suas frustrações e fracassos pensando que sua morte acabaria com seus problemas. No momento anterior ao fato não ocorreu nenhuma violência física ou verbal. O réu reagiu de forma fria, calculista, com aleivosia, sem que a vítima tenha tido chance de se defender, pois a primeira apunhalada foi desferida à traição. Pelas razões expostas, solicitamos a condenação de Hermógenes Saldívar como autor do delito de homicídio qualificado à pena de prisão perpétua ao pagamento das custas processuais.

Conforme já salientado, o promotor tem a função de acusar o réu e pedir a sua condenação. Na história em análise, trata-se de um réu confesso, logo, em primeira análise, não há necessidade de provas materiais, não há o que ser questionado, não há motivo para suscitar dúvidas. Assim, é preciso apenas, nesse arremate da audiência, retomar os fatos e, com base neles, culpar o acusado. É exatamente isso que mostra o discurso da promotoria, ele se vale da fala de Hemógenes, por meio de um discurso indireto, (Ele o responsabiliza por suas frustrações e fracassos) e descreve sua atitude (O réu reagiu de forma fria, calculista, com aleivosia, sem que a vítima tenha tido chance de se defender, pois a primeira apunhalada foi desferida à traição) quebrando a face positiva do réu no momento em que caracteriza sua reação fria, calculista, com aleivosia ${ }^{3}$ e sem chance de defesa para a vítima. O discurso é construído assertivamente, e as palavras que o compõem cumprem a função não só de relatar o acontecimento, mas também a forma como ocorreu. Os atos assertivos compostos por palavras que caracterizam o feito contribuem para a criação da imagem negativa do réu e, consequentemente, para o possível convencimento dos jurados de que ele não

\footnotetext{
${ }^{3}$ Vale registrar o sentido de aleivosia descrito no dicionário é 1. Traição ou crime cometido com falsas demonstrações de amizade; perfídia, deslealdade; 2. Qualidade de quem engana, atraiçoa; dolo, fraude (HOUAISS, 2001, p.147).
} 
apenas matou, mas o fez friamente. Cabe, então, ao advogado de defesa reverter essa imagem negativa construída pelo discurso do promotor.

\section{Bloco 3 - Discurso do advogado de defesa}

O promotor tem razão. O fato aconteceu como descrito pelo senhor. Acho que está fora de questão para todos aqui. Mas me parece que o senhor está olhando um fato isolado, um relatório frio e não um ser humano mergulhado em uma tristeza terrível. Os senhores já se perguntaram o porquê? Por que um homem tranquilo, humilde, um dia comete tal crime em plena luz do dia sem se importar com a presença de testemunhas? Já se perguntaram quem é Hermógenes Saldívar? O promotor pede prisão perpétua. Eu digo que Hermógenes já vive uma prisão perpétua. Da prisão do analfabetismo, da exclusão social, da violação de sua dignidade. A única vez que o Estado prestou atenção nele foi para rotulá-lo como "incapaz". Os senhores viram como e onde vivia o senhor Saldívar, sabiam como ele era tratado pelo patrão. Digo "patrão" em vez de "empregador" porque nunca houve uma relação laboral. Houve apenas uma escravidão. Hermógenes nunca soube dizer qual era o salário dele.

Ele não pode ficar com o próprio nome. Saldívar recebia uma ilusão de salário no fim do mês. A ilusão de uma casa no fim do mês que nunca existiu. Era onde ele se reuniria finalmente com sua família da qual ele fora obrigado a se afastar.

O estudo psiquiátrico oficial alega que não houve violenta emoção porque no momento da agressão não houve nenhuma provocação. O promotor afirma que não houve violência antes do fato. É claro que houve provocação. Há provocação maior do que a escravidão? Do que ser afastado da própria família? Quando Hermógenes ouve seu nome na boca de Latuada, ele já sabia o que aconteceria. A pressão acumulada fez o resto desencadeando um furacão emocional.

Como não há elementos que causem dúvidas sobre a ação do réu, o advogado de defesa inicia seu discurso concordando com o promotor de forma assertiva ( $O$ promotor tem razão. O fato aconteceu como descrito pelo senhor. Acho que está fora de questão para todos aqui). Num primeiro momento, pode até parecer que o advogado concorda com o adágio popular "contra fatos não há argumentos". No entanto, como não há dúvidas sobre a autoria do crime, torna-se até estratégico concordar com ela. Dessa forma, o advogado, nessa circunstância, propõe aos jurados refletir sobre os motivos que levaram o réu à execução do crime.

Elaborar atos assertivos sob a forma afirmativa e sob a forma de pergunta foi a estratégia encontrada pela defesa. A primeira para a descrição dos fatos (parece que o senhor está olhando um fato isolado, um relatório frio e não um ser humano mergulhado em uma tristeza terrível); a segunda para requerer do interlocutor uma resposta (Os senhores já se perguntaram o porquê? Por que um homem tranquilo, 
humilde, um dia comete tal crime em plena luz do dia sem se importar com a presença de testemunhas? Já se perguntaram quem é Hermógenes Saldivar?) É possível perceber como as perguntas lançadas pela defesa exigem que o interlocutor analise os fatos e, ao inseri-lo numa atitude responsiva, constrói-se um ato de ameaça à face negativa do interlocutor.

O discurso da defesa progressivamente parte do ato em si para chegar ao ápice quando tentar criar a ideia de que o réu já foi punido pelo sistema ( $E u$ digo que Hermógenes já vive uma prisão perpétua. Da prisão do analfabetismo, da exclusão social, da violação de sua dignidade. A única vez que o Estado prestou atenção nele foi para rotulá-lo como "incapaz”). É importante salientar que o advogado não cria a imagem negativa do indivíduo, mas trabalha com a noção do coletivo, é a face negativa do Estado que é colocada em xeque, pois não provê aos cidadãos os direitos previstos em lei. A defesa quebra a face positiva do Estado com o intuito de resguardar a do réu, pois este chegou a cometer um ato extremo em decorrência da omissão governamental.

A ausência de condições dignas para a sobrevivência do acusado é novamente ressaltada por meio das assertivas (Os senhores viram como e onde vivia o senhor Saldívar, sabiam como ele era tratado pelo patrão. Digo "patrão” em vez de "empregador" porque nunca houve uma relação laboral. Houve apenas uma escravidão. Hermógenes nunca soube dizer qual era o salário dele). Torna-se cada vez mais clara como a direção palavra-mundo, proposta por Mari (2001), é basilar em textos cuja função é representar o mundo, descrevê-lo e, assim, manifestar um ponto de vista. Seguindo essa trilha, a escolha das palavras na produção dos atos deve ser evidenciada, afinal, de acordo com a defesa, não há relação laboral porque não há vínculo trabalhista, não há uma relação contratual, mas há uma relação servil, há uma escravidão. Novamente a presença de atos de fala negativos (nunca houve, nunca soube) para demarcar contraposição ao discurso da promotoria, sobretudo na parte em que retoma o discurso do promotor: O promotor afirma que não houve violência antes do fato. É claro que houve provocação. Há provocação maior do que a escravidão? Do que ser afastado da própria família? A defesa, de forma assertiva, declara categoricamente que houve provocação e mais uma vez lança perguntas que, como já foi salientado, revelam atos de ameaça à face negativa do interlocutor porque exige dele uma resposta. Nesse caso específico, como é dirigida ao corpo de jurados, 
certamente tem o intuito de, no mínimo, desencadear um momento de reflexão nesse público.

A construção de face dos atores que compõem as cenas no âmbito jurídico é fundamental para produção de discursos argumentativos, porque, embora predomine a ideia de que nessa esfera a finalidade precípua seja a busca pela justiça, Goffman (2011) salienta que "talvez o maior princípio da ordem ritual não seja a justiça, e sim a fachada, e o que qualquer ofensor recebe não é o que ele merece, e sim o que sustentará pelo momento a linha com a qual ele se comprometeu, e através disto a linha com a qual ele comprometeu a interação" (GOFFMAN, 2011, p. 50-51).

\section{Considerações finais}

Os excertos apresentados na análise revelam como a seleção e a organização dos atos de fala funcionam como um fio condutor para a manifestação das ideias de quem os profere e também como eles sinalizam a disposição de o locutor manter a harmonia ou provocar um rompimento nas relações por meio da construção ou desconstrução de face.

Como se trata de excertos extraídos de um filme, e as cenas em análise desvelam os sentimentos do réu confesso em relação ao crime cometido e também ao desfecho da história sob o prisma de um promotor e de um advogado de defesa, já é de se esperar que a linguagem posta em ação, retomando Austin (1990 [1962]), indique um embate de ideias, mostre pontos de vista dissonantes. Cada ator dessa cena diante de um tribunal de júri deve construir um discurso cuja mola propulsora não se assemelhe a um jogo de frescobol no qual a preocupação com o outro é constante, mas se relacione a um jogo de tênis em que os jogadores são adversários e cada qual a seu modo procura convencer os jurados de que o seu pedido deve ser deferido. Assim, a impolidez torna-se relevante na interação entre as partes. Construir ou quebrar a face do réu é condição para, quem sabe, mudar o rumo da história.

El patrón: a radiografia de un crimen é um exemplo de que é possível reverter a lógica da história, um assassino pode ter sua imagem reconfigurada. A defesa, ao construir a face negativa da sociedade, faz com que o protagonista passe da condição de réu para a de vítima de um sistema que não supre a necessidade de seus cidadãos. A tese utilizada pelo advogado defesa ressalta exatamente a ideia presente na epígrafe 
PERcursos Linguísticos • Vitória (ES) • v. 10 • n. 26 • 2020 • ISSN: 2236-2592 •

Dossiê: Linguagem, Comunicação e Cognição•

deste artigo, vida com fome, tocada pelo medo não é justa, sobretudo quando o desequilíbrio vem de fora.

\section{Referências}

ARMENGAUD, F. A pragmática. São Paulo: Parábola Editorial, 2006.

AUSTIN, J. L. Quando dizer é fazer: palavras e ação. Tradução de Danilo Marcondes de Souza Filho. Porto Alegre: Artes Médicas, 1990 [1962].

BROWN, P.; LEVINSON, S. Politeness: some universal in language usage. Cambridge: Cambridge University, 1987 [1978].

CHABROL, C.; BROMBERG, M. Por uma classificação dos atos de fala. In: MARI, H.; MACHADO, I. L.; MELLO, R. (orgs.). Análise do discurso: fundamentos e práticas. Belo Horizonte: FALE/UFMG, 2001. p. 133-155.

FÁVERO, L. L. A cortesia nas interações cotidianas. In: PRETI, Dino (Org.) Cortesia Verbal. São Paulo: Humanitas, 2008, p. 305-322 (Projetos Paralelos - NURC/SP, 9).

GOFFMAN, E. A representação do eu na vida cotidiana. 3. Ed. Petrópolis/RJ: Vozes, 1985 [1975].

Ritual de interação: ensaios sobre o comportamento face a face. Petrópolis: Vozes, 2011 [1967].

HOUAISS. Dicionário Houaiss da Língua Portuguesa. Rio de Janeiro: Objetiva, 2001.

KERBRAT-ORECCHIONI, C. Os atos de linguagem no discurso. Rio de Janeiro: Niterói, 2005.

LEVINSON, S. Pragmática. São Paulo: Martins Fontes, 2007.

LINS, M. P.; MARCHESI, N. M. As estratégias de polidez e a organização tópica em entrevistas impressas. Rio de Janeiro: CIFEFIL, 2010. Disponível em: http://www.filologia.org.br/xiv_cnlf/tomo_3/completo_tomo_3.pdf. Acesso em:2 set. 2020.

LINS, M. P. A pragmática e a análise de textos. Revista (Con)textos linguísticos, v. 2, n. 2, 2008. 2 Disponível em: http://www.periodicos.ufes.br/contextoslinguisticos/article/view/5214/3898. Acesso em: 7 set. 2018.

MARI, H. Atos de fala: notas sobre origens, fundamentos e estrutura. In: MARI, H.; MACHADO, I. L.; MELLO, R. Análise do discurso: fundamentos e práticas. Belo Horizonte: FALE-UFMG, 2001. p. 93-131.

SEARA. I. R. (org.) Cortesia: olhares e (re) invenções. Portugal: Chiado, 2014.

SEARLE, J. R. Os actos de fala: um ensaio de filosofia da linguagem. Coimbra: Almedina, 1981.

YULE, G. Pragmatics. New York: Oxford University Press, 1996. 